\title{
The Impact of Nano-Silver Doses on Microorganism-Deactivation Effectiveness in Water Circulating in a Cooling Tower Cycle
}

\author{
Ewelina Podgórni*, Joanna Boguniewicz-Zabłocka, Iwona Kłosok-Bazan \\ Faculty of Mechanical Engineering, Opole University of Technology, \\ Mikołajczyka 5, 45-271 Opole, Poland
}

Received: March 25, 2015

Accepted: May 11, 2015

\begin{abstract}
Cooling towers are specific heat exchangers that provide perfect conditions for microorganism growth. Currently used disinfection methods involving the use of chlorine, chlorine dioxide, UV, or ozone are effective; however, they have many drawbacks. Silver nanoparticles have become one of the most commonly used nano-materials because of their effective antimicrobial properties and low toxicity to mammalian cells. The purpose of our research was to determine the effectiveness of a biocide containing nano-silver; the size of silver particles on the silica surface did not exceed $20 \mathrm{~nm}$. The biocide (the patent for its recipe is currently pending) was proportioned into water taken from the refrigerating cycle of a cooling tower supplied from surface water intake. In this study five doses of biocide were investigated. Comparison of the effectiveness of doses for both mesophilous and psychrophilic organisms was performed. The toxicity assay substantiated the efficacy of silver nanoparticles, but questioned the reliability of nano-silver biocide because of the aquatic environmental hazard.
\end{abstract}

Keywords: disinfection, industrial water treatment, cooling tower, nano-silver, biocide

\section{Introduction}

The major water consumer in many industries is the cooling system. An essential element of the cooling water system is the installation, in which heat exchange is transferred. The cooling towers are specific heat exchangers that provide perfect conditions for microorganism growth. High humidity, contact with the external environment, and relatively stable temperatures foster the growth of microorganisms, which agglomerate at the boundary of the solid body-liquid phase to form bacterial jelly (biofilm) $\left[1 \mathrm{~m}^{2}\right]$. While anazysing the hazard involved in biofilm development in the technological systems of the cooling towers, one should note that microorganisms (i.e., algae, bacteria, and fungi) may significantly reduce heat transmission due

*e-mail: ewelina.podgorni89@gmail.com to the formation of the biofilm layers and make equipment operation difficult as a result of reduced conduit crosssections [1]. Reduction of heat transmission through the biofilm layers is four times higher than in the case of lime deposits [3]. Additionally, metabolism processes occurring in the microorganisms cause corrosion, which can result in system damage [4].

Currently used disinfection methods involving the use of chlorine, chlorine dioxide, UV, or ozone are effective; however, they have many drawbacks [5]. The development of new sustainable technologies to prevent microbial growth and scaling in industrial water systems is an important subject. Prevention technologies reduce the use of chemicals for water conditioning and cleaning and increase the possibilities of water recycling and re-use. Modern challenges today are to attain the appropriate disinfection methods without causing any harm through disinfection of 
by-products, which in turn requires the use of conventional chemical disinfectants, were the need for point-of-use water treatment and recycling systems is on the increase, which also necessitates the need to use new technologies for more effective disinfection and microbial control.

Silver nanoparticles have become one of the most commonly used nano-materials in industrial systems because of their effective antimicrobial properties and low toxicity to mammalian cells [6]. However, the mechanism of nano-silver functioning has not been entirely explained, and there are still intensive studies in progress aimed at elucidating it. Suggested processes of bacteria deactivation by the nanosilver include catalytic oxygenation, reactions with the bacteria cell wall, protein denaturation, and bonds with the DNA [7]. Another indicated mechanism of functioning includes the interaction of silver with thiol groups (-SH) in bacteria respiration enzymes, which inhibit breathing and cause cell atrophy. Silver may also bond with microorganism protein, which leads to its deactivation, or it may merge with walls of microorganism cells, thus inhibiting their respiration process. It also has been found that in Gramnegative bacteria, silver nanoparticles may bond with the bacteria cell wall surface and disturb its function, or they may penetrate the bacteria, where they will show a tendency to merge with compounds that contain sulphur and phosphorus, such as DNA, which may result in their damage [8]. Completed studies prove that nano-silver effectiveness depends on the size of applied particles and grows as the size of these particles declines. Due to the high reactivity of nanoparticles, the same effect is attainable when using smaller concentrations than in the case of conventional silver particles [9]. The silver nanoparticle has a larger active surface area than conventional silver ions, which makes it more chemically and biologically reactive $[10,11]$. An attempt to use biocide based on nano-silver particles in the cooling towers was made by Kłosok-Bazan [12]. This work aimed to study the application of different doses to enhance the disinfection process for the microorganism's deactivation. Two groups of microorganisms were investigated and their survival assessed.

\section{Materials and Methods}

The purpose of our research was to determine the effectiveness of a biocide containing nano-silver; the size of silver particles on the silica surface did not exceed $20 \mathrm{~nm}$. The biocide (the patent for its recipe is currently pending) was proportioned into water taken from the refrigerating cycle of the cooling tower supplied from surface water intake. Before bringing the water into the cycle, it was treated using typical technical process equipment. The discussed industry used screening, coagulation, sedimentaion, filtration, and ion exchange. Water taken from the system $\left(1 \mathrm{dm}^{3}\right)$ was subject to a disinfection process in laboratory conditions by way of adding liquid nano-silver solution in the following doses: $0.1 \mathrm{~g} / \mathrm{m}^{3}, 0.5 \mathrm{~g} / \mathrm{m}^{3}, 1 \mathrm{~g} / \mathrm{m}^{3}, 1.5 \mathrm{~g} / \mathrm{m}^{3}$, and $2.0 \mathrm{~g} / \mathrm{m}^{3}$. The choice of nano-silver dose depended on the technological conditions, meaning that the following facts were taken into account while selecting the dose: desalination by-products and sludge discharge from the system proceeds without silver precipitation processes. Penetration of large quantities of silver into the environment may cause loss of balance in the biosystem. After adding the biocide, the samples were mixed and left in laboratory conditions in order to ensure appropriate contact time. It was assumed that contact duration for water and biocide should be at least one hour. After that time, $1 \mathrm{~cm}^{3}$ of water was taken from each sample in order to carry out microbiological analyses. At the same time, the microbiological tests were performed in order to check the samples containing pure circulating water. In order to reduce errors and to enable performance of statistical evaluation of obtained results, the tests were repeated six times in several test series.

Microbiological analyses were carried out according to the standard EN ISO 6222:1999. Quantitative determination of the microorganisms was carried out by counting bacteria colonies, which grew on nutritive agar after incubation in aerobic conditions at $36^{\circ} \mathrm{C}$ and $22^{\circ} \mathrm{C}$.

The following analyses were performed in the analyzed water:

- Total number of microorganisms at $36 \pm 2^{\circ} \mathrm{C}$ after $48 \mathrm{~h}$ : mesophilous organisms were determined at this temperature, for which optimal development and growth temperature ranges from $30^{\circ} \mathrm{C}$ to $40^{\circ} \mathrm{C}$. Pathogenic bacteria may appear among them, since their optimal temperature is the same as that of the human body.

- Total number of microorganisms at $22 \pm 2^{\circ} \mathrm{C}$ after $72 \mathrm{~h}$ : psychrophilic organisms were determined at this temperature, which perish below $0^{\circ} \mathrm{C}$ and above $30^{\circ} \mathrm{C}$ and grow best at $15^{\circ} \mathrm{C}$. These microbes do not cause a serious hazard for humans; however, their presence in the cooling water has a negative impact on the state of facilities and thermal conductivity.

The effectiveness of produced biocide was determined according to the following relation:

$$
S=\left(1-N / N_{0}\right) \times 100 \%
$$

...where:

$S$ - biocide effectiveness [\%]

$N$ - average number of bacteria after disinfection $\left[\mathrm{cfu} / \mathrm{cm}^{3}\right]$

$N_{0}$ - average number of bacteria before disinfection $\left[\mathrm{cfu} / \mathrm{cm}^{3}\right]$

\section{Results and Discussion}

Water taken from the technological system of a refrigerating cycle in the cooling tower was used in the biocide effectiveness tests. The cooling tower was supplied with a surface water intake. Before bringing the water into the cycle, it was treated in typical technical process equipment. The quality of water used in the tests matched the parameters specified in the standard VDI 3803 concerning water quality in the cooling systems. The reaction - i.e. the mea- 
Table 1. The results of tests concerning the effectiveness of silver nanoparticle action on mesophilous organisms.

\begin{tabular}{|l|c|c|c|c|c|c|}
\hline \multirow{2}{*}{} & \multicolumn{5}{|c|}{ General count of mesophilous organisms [CFU] } \\
\cline { 2 - 7 } & \multirow{2}{*}{$\begin{array}{c}\text { Water from cooling } \\
\text { system }\end{array}$} & \multicolumn{5}{|c|}{ Nano-silver dose } \\
\cline { 2 - 7 } & $0.1 \mathrm{~g} / \mathrm{m}^{3}$ & $0.5 \mathrm{~g} / \mathrm{m}^{3}$ & $1.0 \mathrm{~g} / \mathrm{m}^{3}$ & $1.5 \mathrm{~g} / \mathrm{m}^{3}$ & $32.0 \mathrm{~g} / \mathrm{m}^{3}$ \\
\hline Average & 74 & 52 & 44 & 42 & 39 & 32.5 \\
\hline Median & 73.5 & 51.0 & 43.5 & 41.5 & 39 & 30 \\
\hline Min. & 70 & 48 & 40 & 48 & 46 & 37 \\
\hline Max. & 76 & 56 & 50 & 3.35 & 4.88 & 2.50 \\
\hline SD & 2.87 & 2.75 & 3.00 & & 39 \\
\hline
\end{tabular}

$\mathrm{SD}$ - standard deviation

surement significance from the point of view of the water's corrosive properties and the tendency to precipitate sediments - was compliant with the standard guidelines and was $8.3 \pm 1$, with alkalinity fluctuating around $1.6 \mathrm{val} / \mathrm{m}^{3}$. Monitoring of hardness can be greatly helpful in keeping track of scaling potential, a temporary hardness of analyzed water was kept under $0.7 \mathrm{~mol} / \mathrm{m}^{3}$. Electrical conductivity, strictly related to water salinity, oscillated near $600 \mu \mathrm{S} / \mathrm{cm}$, being a safe value, since water characterized by high conductivity shows corrosive properties. Concentration of chlorides in the circulating water is the check index of the number of concentration cycles. During the tests, chloride concentrations ranged between 56 and $59 \mathrm{~g} / \mathrm{m}^{3}$, and sulphate concentrations ranged from 114 to $119 \mathrm{~g} / \mathrm{m}^{3}$. Suspended matter is the measure of the quantity of insoluble particles, and precipitation and accumulation of them may reduce the calorific effect. The taken water was colourless, with small volumes of suspended solids reaching $11 \mathrm{~g} / \mathrm{m}^{3}$. On the other hand, oxygen consumption is the index of susceptibility to biological bloom, e.g., increases in oxygen consumption may prove the occurrence of easily assimilable organic compounds in water, which translates into a greater tendency to form biofilm. The amount of organic compounds determined using the permanganate method during the examined period ranged from 4.43 to $5.5 \mathrm{gO}_{2} / \mathrm{m}^{3}$.
The industrial recirculating system comparable to the analyzed system is an ideal environment for microbiological growth. The combination of temperature, contact with oxygen, and relatively slow water flow sets the stage for exponential growth of microorganisms. The amount of bacteria in three test series ranged from 70 to $121 \mathrm{cfu} / \mathrm{cm}^{3}$ for bacteria determined at a temperature of $36^{\circ} \mathrm{C}$, and from 92 to $690 \mathrm{cfu} / \mathrm{cm}^{3}$ in the case of microorganisms determined at $22^{\circ} \mathrm{C}$. This large discrepancy is due to the different cycle time, hence conditions in which water was collected to test from the cooling system.

Demonstrated test results (Table 1) unequivocally indicate the impact of the nano-silver dose on deactivation effectiveness for this group of microorganisms. It can be seen that the best efficiency was obtained for $2.0 \mathrm{~g} / \mathrm{m}^{3}$ dose. However, comparable results were obtained for doses of $0.5 \mathrm{~g} / \mathrm{m}^{3}, 1.0 \mathrm{~g} / \mathrm{m}^{3}$, and $1.5 \mathrm{~g} / \mathrm{m}^{3}$.

Analysis results indicate (Fig. 1) linear correlation between the applied nano-silver dose and microorganismdeactivation effectiveness. Pearson correlation coefficient was 0.97 .

With respect to psychrophilic microorganisms, the total number of microorganisms determined at $22^{\circ} \mathrm{C}$ ranged from 92 to $98 \mathrm{cfu} / \mathrm{cm}^{3}$. The average number of estimated microorganisms was $95 \mathrm{cfu} / \mathrm{cm}^{3}$. Table 2 shows the results

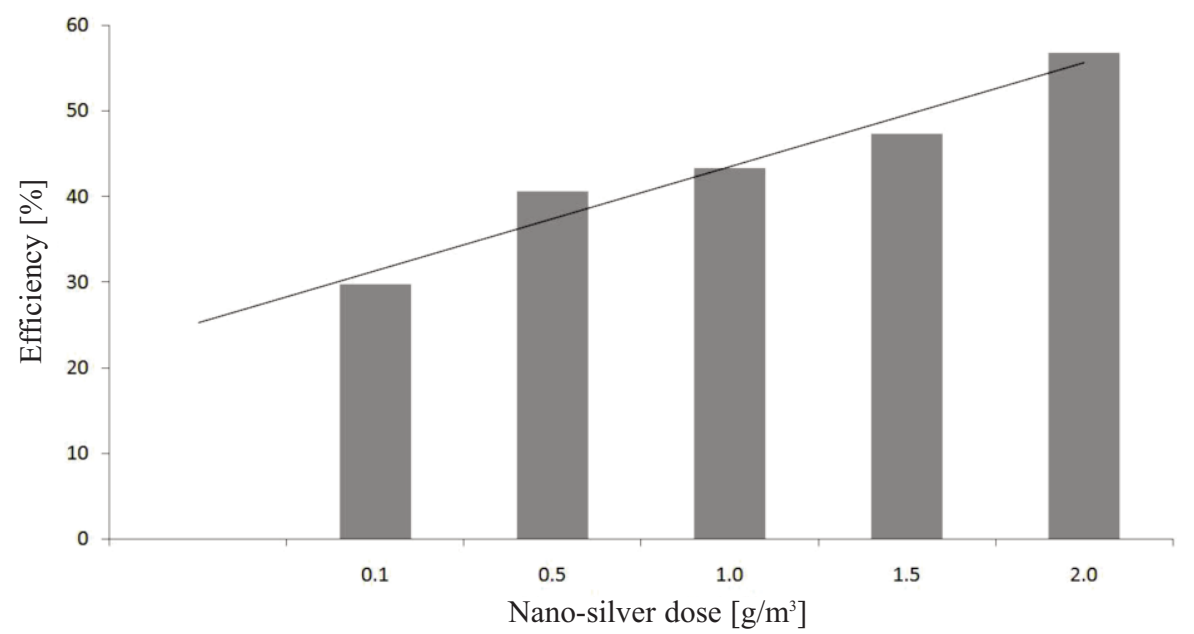

Fig. 1. The impact of nano-silver dose on mesophilous microorganism-deactivation effectiveness. 
Table 2. The results of tests concerning the effectiveness of silver nanoparticle action on psychrophilic microorganisms.

\begin{tabular}{|c|c|c|c|c|c|c|}
\hline & \multicolumn{6}{|c|}{ General count of psychrophilic microorganisms [CFU] } \\
\hline & \multirow{2}{*}{$\begin{array}{l}\text { Water from cooling } \\
\text { system }\end{array}$} & \multicolumn{5}{|c|}{ Nano-silver dose } \\
\hline & & $0.1 \mathrm{~g} / \mathrm{m}^{3}$ & $0.5 \mathrm{~g} / \mathrm{m}^{3}$ & $1.0 \mathrm{~g} / \mathrm{m}^{3}$ & $1.5 \mathrm{~g} / \mathrm{m}^{3}$ & $2.0 \mathrm{~g} / \mathrm{m}^{3}$ \\
\hline Average & 95 & 66 & 64 & 78 & 81 & 77 \\
\hline Median & 95.5 & 65.5 & 63.5 & 78.5 & 81.0 & 78.5 \\
\hline Min. & 92 & 63 & 61 & 74 & 77 & 70 \\
\hline Max & 98 & 68 & 67 & 81 & 85 & 83 \\
\hline SD & 2.31 & 2.21 & 1.97 & 2.54 & 2.64 & 4.50 \\
\hline
\end{tabular}

$\mathrm{SD}$ - standard deviation

of tests concerning the effectiveness of silver nanoparticle action on psychrophilic microorganisms.

The experimental studies show quite high efficiency for mesophilous organisms (from 30\% to 57\%) and lower for psychrophilic organisms. What is more, increasing doses for psychrophilic organisms from 1 to $2 \mathrm{~g} / \mathrm{m}^{3}$ did not lead to further reduction of this group of organisms.

Fig. 2 presents the impact of nano-silver dose on psychrophilic microorganism deactivation effectiveness. It can be seen that values of maximal process efficiency do not exceed $35 \%$. Furthermore, it can be found that increasing biocide dose does not affect the process. Analysis shows that the highest efficiency has been reported at a relatively low dose of $0.5 \mathrm{~g} / \mathrm{m}^{3}$. It could be a natural ability of a widely occurring bacteria to adapt fairly rapidly to the antimicrobial action of nanosilver. Antimicrobial action of nanosilver is not universal and the widespread use of these products should be taken into consideration with the potential for longer-term adverse outcomes.

In the following part of the research the impact of initial conditions on the effectiveness of nano-silver has been investigated. A further two series of studies, six tests each, were performed. Summary of the results for the mesophilous organisms are shown in Table 3 and for the psychrophilic microorganisms in Table 4.
Test results presented in Table 3 indicate that the highest impact of the nano-silver dose on deactivation effectiveness for mesophilous organisms is on series A more than B. Analysis results for series A and B indicate (Fig. 3) linear correlation between the applied nano-silver dose and microorganism-deactivation effectiveness. Pearson correlation coefficients for both test series were quite high: 0.935 for series A and 0.977 for series B.

With respect to psychrophilic microorganisms, a significant change in their amount in water taken from the system was observed. During test series A, the total number of microorganisms determined at a temperature of $22^{\circ} \mathrm{C}$ ranged from 630 to $690 \mathrm{cfu} / \mathrm{cm}^{3}$, while for series I, described previously, the average total number was $95 \mathrm{cfu} / \mathrm{cm}^{3}$. The total number of microorganisms estimated in test series B was $228 \mathrm{cfu} / \mathrm{cm}^{3}$. These significant changes most probably result from the fact that the system was supplied with fresh, chemically treated water.

It is worth noting that water circulating in the cooling towers partially evaporates (increasing salinity) and sediments (various types of deposits), the circulating system is blown down, and the system is supplied with fresh water from the treatment plant. This happens in the cooling tower plants in specific technology cycles. The water taken for research was collected from circulating water in

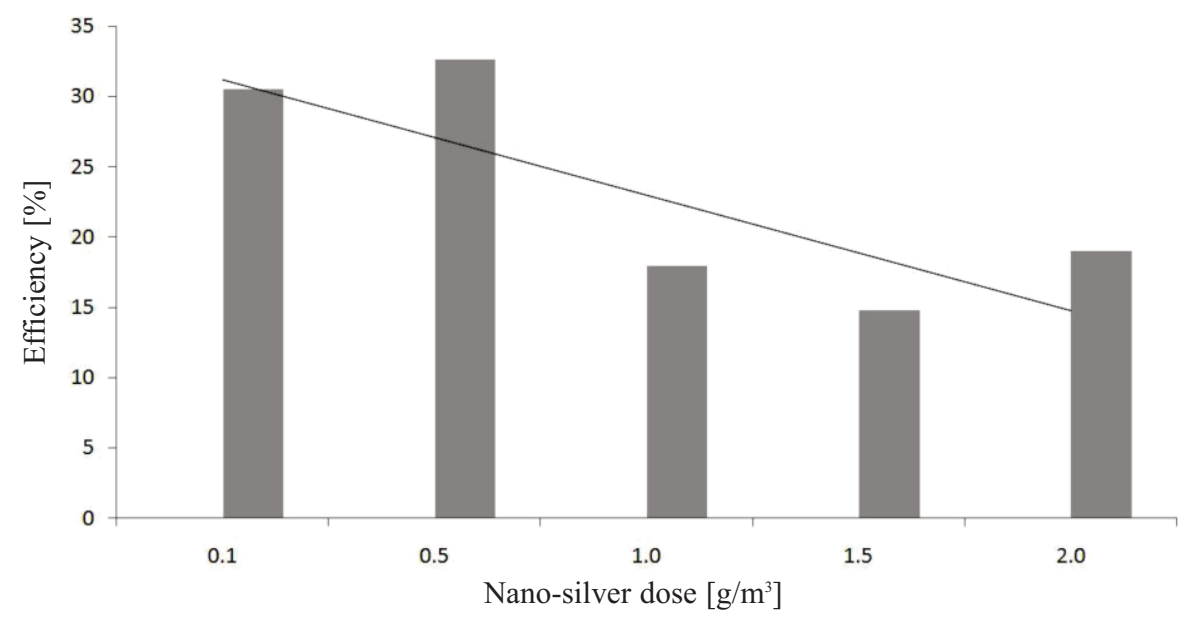

Fig. 2. The impact of nano-silver doses on psychrophilic microorganism-deactivation effectiveness. 
Table 3. The results of two other tests concerning the effectiveness of silver nanoparticle action on mesophilous organisms.

\begin{tabular}{|c|c|c|c|c|c|}
\hline & \multicolumn{5}{|c|}{ General count of mesophilous organisms [CFU] } \\
\hline & \multirow{2}{*}{$\begin{array}{l}\text { Water from cooling } \\
\text { system }\end{array}$} & \multicolumn{4}{|c|}{ Nano-silver dose } \\
\hline & & $0.1 \mathrm{~g} / \mathrm{m}^{3}$ & $0.5 \mathrm{~g} / \mathrm{m}^{3}$ & $1.0 \mathrm{~g} / \mathrm{m}^{3}$ & $1.5 \mathrm{~g} / \mathrm{m}^{3}$ \\
\hline \multicolumn{6}{|c|}{ Series A } \\
\hline Average & 109 & 60 & 56 & 46 & 59 \\
\hline Median & 109 & 60 & 57.5 & 46 & 59.5 \\
\hline Min. & 104 & 52 & 46 & 42 & 53 \\
\hline Max & 114 & 65 & 61 & 51 & 66 \\
\hline SD & 3.41 & 4.26 & 5.01 & 2.91 & 5.15 \\
\hline \multicolumn{6}{|c|}{ Series B } \\
\hline Average & 114 & 86 & - & 81 & 75 \\
\hline Median & 115 & 85.5 & - & 80.5 & 75 \\
\hline Min. & 102 & 76 & - & 68 & 66 \\
\hline Max & 121 & 96 & - & 92 & 79 \\
\hline SD & 7.04 & 6.13 & - & 7.57 & 5.12 \\
\hline
\end{tabular}

$\mathrm{SD}$ - standard deviation

different stages of the cycle, hence considerable discrepancy in the quality of water that has been tested. Table 4 shows the results of tests concerning the effectiveness of silver nanoparticle action on psychrophilic microorganisms.

While analysing the obtained results, it should be stated that in spite of high diversification in the number of microorganisms in water subject to the disinfection process involving the use of silver nanoparticles, the amount of microorganisms determined in water after the process has not shown great diversification. Therefore, it may be concluded that the initial number of microorganisms in water subject to disinfection with nano-silver is not an essential parameter affecting the final effects of the process. One may assume that there are groups of microorganisms adapting to the presence of nano-silver and capable of avoiding its cytotoxic properties, which is confirmed by a recent study [13]. These adaptations may concern counteracting both minor disturbances in the redox balance of cells and lethal levels of ROS stimulation generated by nano-silver. However, this issue requires further study. Considering the deactivation effectiveness for psychrophilic microorganisms resulting from the application of varying nano-silver doses, it should be stated that no significant correlations were observed (Fig. 4) between the applied nano-silver doses and disinfection process effectiveness. The Pearson correlation coefficient had a negative value (-0.81), which would suggest that the growing nano-silver dose had negative impacts on process performance.

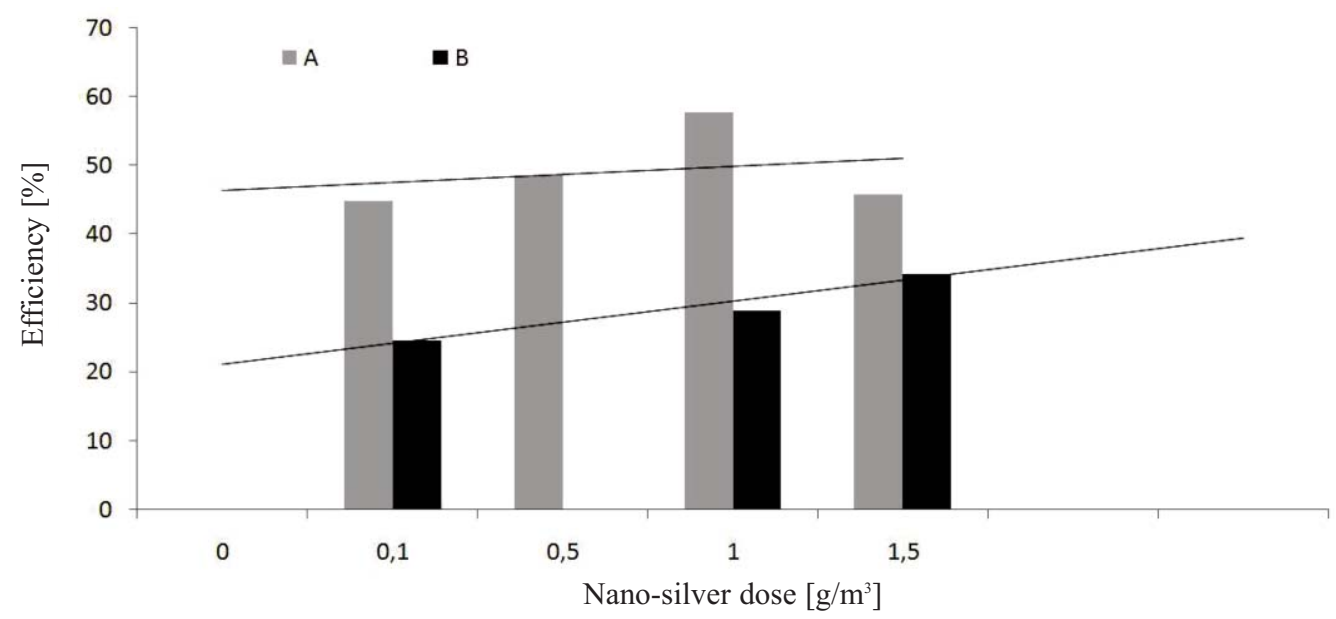

Fig. 3. The impact of nano-silver dose on mesophilous microorganism-deactivation effectiveness. 
Table 4. The results of tests concerning the effectiveness of silver nanoparticle action on psychrophilic microorganisms.

\begin{tabular}{|c|c|c|c|c|c|}
\hline & \multicolumn{5}{|c|}{ General count of psychrophilic microorganisms [CFU] } \\
\hline & \multirow{2}{*}{$\begin{array}{l}\text { Water from cooling } \\
\text { system }\end{array}$} & \multicolumn{4}{|c|}{ Nano-silver dose } \\
\hline & & $0.1 \mathrm{~g} / \mathrm{m}^{3}$ & $0.5 \mathrm{~g} / \mathrm{m}^{3}$ & $1.0 \mathrm{~g} / \mathrm{m}^{3}$ & $1.5 \mathrm{~g} / \mathrm{m}^{3}$ \\
\hline \multicolumn{6}{|c|}{ Series A } \\
\hline Average & 657 & 124 & 122 & 80 & 104 \\
\hline Median & 655 & 124 & 121 & 80 & 107 \\
\hline Min. & 630 & 118 & 115 & 74 & 91 \\
\hline Max & 690 & 132 & 130 & 86 & 117 \\
\hline SD & 20.34 & 4.82 & 5.30 & 3.87 & 8.53 \\
\hline \multicolumn{6}{|c|}{ Series B } \\
\hline Average & 228 & 162 & - & 117.5 & 124 \\
\hline Median & 234 & 162 & - & 118 & 124.5 \\
\hline Min. & 201 & 158 & - & 113 & 120 \\
\hline Max & 242 & 166 & - & 121 & 128 \\
\hline SD & 14.1 & 2.43 & - & 2.75 & 2.52 \\
\hline
\end{tabular}

$\mathrm{SD}$ - standard deviation

\section{Conclusions}

In the case of nano-silver particles, the desired toxicity toward bacteria, fungi, and viruses will unfortunately also translate into toxicity toward organisms present in the natural environment. Obtained results of the studies on toxicity of silver nanoparticles with reference to the aquatic organisms of Daphnia magna have proven that certain effects may be observed at very low concentrations of only $0.002 \mathrm{~g} / \mathrm{m}^{3}$ (contact duration, $48 \mathrm{~h}$ ). For Leuciscus idus fish, the changes have been observed after $96 \mathrm{~h}$ at a concentration of $0.029 \mathrm{~g} / \mathrm{m}^{3}$. However, the negative impact of silver nanoparticles with reference to plants has been observed on algae, which react by inhibiting their growth at nano-silver concentrations reaching $0.007 \mathrm{~g} / \mathrm{m}^{3}$ [10]. In the case of applying nano-silver-based biocides to cooling tower water cycles, there is the potential risk of releasing excessive nano-silver amounts into the environment, since water for cooling purposes circulates in the cooling tower-condenser system and, after having reached a predetermined concentration level due to the evaporation of pure $\mathrm{H}_{2} \mathrm{O}$, is partially released into the natural environment as the so-called desalination by-product. Such sewage as a desalination byproduct is characterized by high concentrations of substances present in natural water and substances brought to the system during water conditioning processes. Unfortunately, their pre-treatment before discharge most often comes down to reducing the concentration of suspended matter and to $\mathrm{pH}$ value correction. So far, no studies have been carried out on the effectiveness of nano-silver

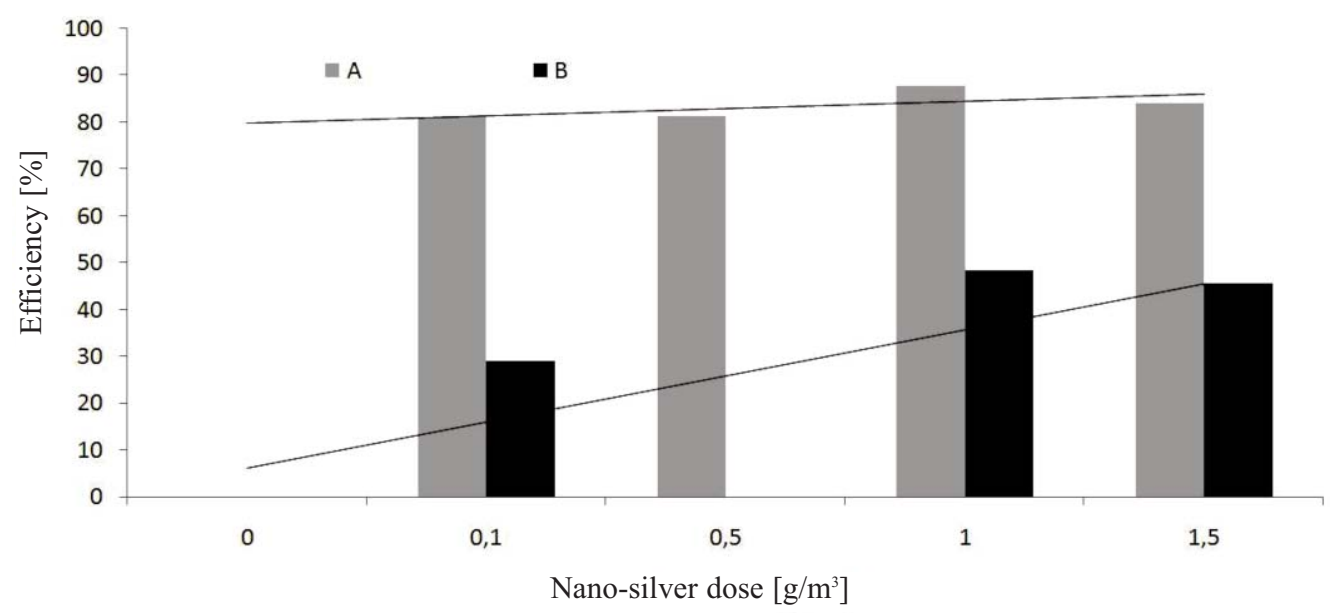

Fig. 4. The impact of nano-silver dose on psychrophilic microorganism-deactivation effectiveness. 
precipitation from desalination by-products or on the impact of temperature on the process. Therefore, before making potential decisions as to whether agents of this sort should be used in cooling tower systems, it is necessary to perform further studies on nano-silver precipitation processes. The current authors aim to evaluate the effects of initial water quality and temperature on the process.

\section{References}

1. HAUER T. Phototrophic biofilms on the interior walls of concrete Iterson-type cooling towers. J. Appl. Phycol. 22, 733, 2010 .

2. LIU F., CHANG X., YANG F.,WANG Y., WANG F., DONG W. ZHAO Ch. Effect of oxidizing and non-oxidizing biocides on biofilm at different substrate levels in the model recirculating cooling water system. World J. Microb. Biot. 27, 2989, 2011.

3. EZGI H., AYTEN K. Investigation of N-acyl homoserine lactone (AHL) molecule production in Gram-negative bacteria isolated from cooling tower water and biofilm samples. Folia Microbiol. 58, 349, 2013.

4. KOEWZAN B. Analysis of Biofilms - Their Formation and Functioning. Ochrona Srodowiska 2011, 33, (4), 3, 2011 [In Polish].

5. Guidelines for the Prevention of Uncontrolled Bacteriological Contamination, including Legionella
Pneumophila, in Cooling Towers and Evaporative Condensers EUROVENT 2011 9/7, 2011.

6. CHOK H., PARK J. The study of antimicrobial activity and preservative effects of nanosilver ingredient. Electrochim. Acta 51, (5), 956, 2005.

7. LANKVELD D., OOMEN A., KRYSTEK P., NEIGH A., TROOST-DE JONG A., NOORLANDER C.W., VAN EIJKEREN J.C., GEERTSMA R.E., DE JONG W.H. The kinetics of the tissue distribution of silver nanoparticles of different sizes. Biomaterial 31, 8350, 2010.

8. ARYA V., KOMAL R., KAUR M., GOYAL A. Silver Nanoparticles as a Potent Antimicrobial Agent: A Review. Pharmacologyonline 3, 118, 2011.

9. SIONKOWSKI G., KACZMAREK H. Polymers with silver nanoparticles - selected systems, preparation, properties and applications. Polimery 55, 545, 2010 [In Polish].

10. PIERŚCIENIAK M., BARAŃSKI A., GWOREK B. Nanoparticles. Environmental hazard. Przegląd Chemiczny 91/4, 564, 2012 [In Polish].

11. CHOI O., CHANG-PING Y., ESTEBAN G., ZHIQIANG $\mathrm{H}$. Interactions of nanosilver with Escherichia coli cells in planktonic and biofilm cultures. Water Res. 44, 6096, 2010.

12. KŁOSOK-BAZAN I. Use of Nanosilver for Water Conditioning in Cooling Tower Circulation System. Ochrona Srodowiska, 36, (2), 43, 2014 [In Polish].

13. GUNAWAN C., YANG TEOH W., MARQUIS C., AMAL R. Induced Adaptation of Bacillus sp. to Antimicrobial Nanosilver. Small 9, 3554, 2013. 
